\author{
Vlada Niehina \\ Oles Honchar Dnipro National University (Dnipro, Ukraine) \\ https://orcid.org/oooo-00o2-2293-423X \\ e-mail:vnegina17@gmail.com

\section{Oleksandr Vysotskyi}

Oles Honchar Dnipro National University (Dnipro, Ukraine)

https://orcid. org/oooo-0oo3-0712-8499

e-mail:vysalek@gmail.com

\title{
APPLICATION OF ISRAELI FOREIGN POLICY TECHNOLOGIES THROUGH THE PRO-ISRAEL LOBBY IN THE UNITED STATES
}

\section{Abstract}

Israeli-American relations are based on common democratic values. The pro-Israel lobby is considered one of the most powerful, well-funded, and has ties to American politicians it supports during the election campaign. But lobbyists are faced with the task of obtaining pro-Israel support in important issues for the Jewish state: security, the status of Jewish settlements, Iran's nuclear program, financial support under the «Memorandum of understanding on military assistance» and improving relations with the Arab world through the mediation of the United States. Since the lobby consists of various organizations and groups, there are certain contradictions in views between them. Special attention is paid to the implementation of the foreign policy of the Jewish state by AIPAC and J-Street organizations, as the largest and most influential in the United States. The technologies of Israel's foreign policy through lobbying proIsrael groups in the United States are: financial support for congressmen and senators, organizing trips to the Jewish state, initiating and holding discussions of problems in Congress and the Senate, organizing annual congresses with the participation of American and Israeli officials.

Keywords: foreign policy technologies, communication, international relations, pro-Israel lobby, external influence, lobbying technologies. 


\section{Нєгіна Влада Русланівна}

Дніпровський національний університет імені Олеся Гончара

(м. Дніпро, Украӥна)

https://orcid.org/oooo-0oo2-2293-423X

e-mail:vnegina17@gmail.com

\section{Висоцький Олександр Юрійович}

Дніпровсъкий національний університет імені Олеся Гончара

(м. Дніпро, Україна)

https://orcid. org/oooo-0oo3-0712-8499

e-mail:vysalek@gmail.com

\section{РЕАЛІЗАЦІЯ ТЕХНОЛОГІЙ ЗОВНІШНЬОЇ ПОЛІТИКИ ІЗРАЇЛЮ ЧЕРЕЗ ПРОІЗРАЇЛЬСЬКЕ ЛОБІ У США}

\section{Резюме}

Актуальність статті зумовлена необхідністю осмислення технологічного арсеналу зовнішньої політики Ізраїлю як держави, що має найбільш потужне лобі в США. Фактично, діяльність проізраїльського лобі в США є однією із важливих технологій Ізраїлю на міжнародній арені, що своєю чергою може бути конкретизована як сукупність персональних та інституційних технологій. Мета статті-визначити ефективність та результативність проізраїльського лобі у Сполучених Штатах у контексті реалізації технологій зовнішньої політики Ізраїлю.

Проізраїльське лобі представлено не як єдине ціле, але як конгломерат трьох різних та конкуруючих лобі, які часто працюють суперечливо між собою, але мають одну ціль - покращення американсько-ізраїльських відносин та вирішення безпекових питань Ізраїля. Проізраїльське лобі у Сполучених Штатах вважається ефективним, оскільки єврейська держава отримує двопартійну підтримку у вигляді щорічної фінансової допомоги.

Підтримка Ізраїлю є однією із ключових у зовнішній політиці Сполучених Штатів. Опорою ізраїльсько-американських відносин є спільні 204 
демократичні цінності. Проізраїльське лобі вважається одним із найпотужніших, добре фінансується, має зв'язки з американськими політиками, яких підтримує під час передвиборчої кампанії. Натомість перед лобістами постає задача отримати проізраїльську підтримку в важливих для єврейської держави питаннях: безпека, статус єврейських поселень, ядерна програма Ірану, фінансова підтримка в рамках «Меморандуму про взаєморозуміння щодо військової допомоги» та поліпшення відносин з арабським світом через посередництво Сполучених Штатів. Оскільки лобі складається з різноманітних організацій та груп, між ними існують певні суперечності у поглядах. Особлива увага приділяється реалізації зовнішньої політики єврейської держави організаціями AIPAC та J-Street, як найбільш масштабних та впливових у Сполучених Штатах. Технологіями зовнішньої політики Ізраїлю через лобіювання проізраїльских груп у Сполучених Штатах є: фінансова підтримка конгресменів та сенаторів, організація поїздок до єврейської держави, ініціювання та проведення обговорення проблем у Конгресі та Сенаті, влаштування щорічних з’їдів за участю американських та ізраїльських високопосадовців.

Ключові слова: технології зовнішньої політики, комунікація, міжнародні відносини, проізраїльське лобі, зовнішній вплив, лобістські технології.

\section{Bcmyn}

Актуальність статті зумовлена необхідністю осмислення технологічного арсеналу зовнішньої політики Ізраїлю як держави, що має найбільш потужне лобі в США. Фактично, діяльність проізраїльського лобі в США є однією із важливих технологій Ізраїлю на міжнародній арені, що своєю чергою може бути конкретизована як сукупність персональних та інституційних технологій. Тому в контексті розкриття теми статті важливо розглянути офіційні групи у проізраїльському лобі, щоб визначити вплив лобі в цілому. Групи інтересів у проізраїльському лобі, до яких ми в першу чергу звернемось у своєму аналізі-це «Американо-ізраїльський комітет громадських зв'язків» (AIPAC) та J-Street. AIPAC- одна з найбільш відомих груп інтересів у Сполучених Штатах. Хоча AIPAC безпосередньо не сприяє жодній кампанії, він поєднує потенційних донорів та лобістські групи з кампаніями чи законодавцями [17]. AIPAC у цілому є більш консервативним і більшу частину своєї підтримки узгоджує з партією «Лікуд», консервативною правлячою партією Ізраїлю. J-Street $\epsilon$ однією з найбільш відомих груп ліберальних інтересів у проізраїльському лобі. Останніми роками він значно розширив свій вплив. 32008 року J-Street $€$ одним із найбільших учасників проізраїльського лобі. Виходячи з вищенаведеного, метою статті $€$ визначити ефективність та результативність проізраїльського лобі у Сполучених Штатах у контексті реалізації технологій зовнішньої політики Ізраїлю. 
Методологічною основою дослідження стали технологічний, діалектичний та герменевтичний підходи. Технологічний підхід, що використовується для цілісного вивчення технологій зовнішньої політики держав світу, уможливлює осмислення світових процесів як результуючої діяльності міжнародних суб'єктів, які борються за владу на глобальному рівні та здійснюють відповідні дії та заходи, спрямовані на забезпечення їх інтересів. Технологічний підхід грунтується на гнучкому поєднанні методологічного арсеналу, який притаманний філософським, загальнонауковим і спеціально-науковим підходам. Це, насамперед, історичний, порівняльний та функціональний методи. Діалектичний підхід дозволив як синтезувати в межах технологічного підходу різні за своїм змістом та спрямованістю пізнавальні підходи, так і розглянути формування та здійснення технологій зовнішньої політики Ізраїлю як постійний процес нововведень, обумовлений пристосуванням до різноманітних контекстів мінливої світової реальності. Герменевтичний підхід дав можливість розглянути технології зовнішньої політики Ізраїлю як ефективні засоби створення та нав'язування вигідної для нього інтерпретації міжнародної реальності лобістськими організаціями в США, що зумовило успішне виконання ним поточних завдань на міжнародної арені для реалізації власних інтересів.

\section{Результати}

Термін «проізраїльськелобі» зазвичай використовуєтьсябезбудь-яких уточнень або визначень. Раніше його часто ототожнювали з «Американоізраїльським комітетом громадських зв'язків» (AIPAC) так, ніби ці два визначення стають практично ідентичними. Хоча AIPAC виділяється як найстаріша проізраїльська лобістська група у Сполучених Штатах - i навіть називає себе «проізраїльським лобі Америки», вона одна з багатьох інших організацій та не володіє монополією на проізраїльську пропаганду. На відміну від деяких інших американських лобі, визначених єдиною організацією, існує безліч проізраїльських лобістських груп, що просувають різні програми і точки зору. Крім того, проізраїльські групи інтересів не завжди підтримують політику, яка повністю відповідає тому, що хоче уряд Ізраїлю. Хоча проізраїльські групи інтересів і підтримують певну політику, яка часто узгоджується із ізраїльськими інтересами, ці відносини не демонструють поточного стану цього лобі. Тому неправильно ототожнювати проізраїльське лобі з ізраїльським урядом, вважаючи, що лобі повністю йому зобов'язане та виконує усі його вказівки. Оскільки, проізраїльські групи є незалежними суб’єктами, погляди яких можуть різнитися, іноді значно, від уряду Ізраїлю, і що перші можуть вживати заходів, яким можуть протистояти другі. Наприклад, в перші роки мирного процесу в Осло уряд Іцхака Рабина скаржився, що деякі проізраїльські організації у Сполучених Штатах діють проти його політики і намагаються підірвати мирний процес. 
Проізраїльське лобі, хоча і не $є$ іноземним лобі у США, та просуває політику, яка, на їх думку, є вигідною для держави Ізраїль. Як і більшість лобістських груп, використовують вплив грошей та інших політичних засобів для стратегічної підтримки чи підриву впливових членів Конгресу. Проізраїльське лобі іноді не є унітарною групою інтересів. Складається з груп інтересів та осіб, які прагнуть сприяти інтересам Ізраїлю, активно намагаючись впливати на законодавство та дискурс у Сполучених Штатах. Лобі включає окремих донорів, ПКК та групи інтересів, які допомагають заохочувати проізраїльську політику. Існують певні проблеми, які створюють суттєві розбіжності між членами проізраїльського лобі. Подібно до різних підходів до просування інтересів США, на прикладі політичних партій у США, існують різні способи просування інтересів Ізраїлю. Проблеми, які $\epsilon$ розбіжними, такі як триваючий конфлікт між Ізраїлем та палестинцями, участь США у ядерній угоді з Іраном, створили розриви у проізраїльському лобі. Отже, сьогодні не можна припустити, що лобісти контролюються централізовано або завжди є єдиними у своєму повідомленні, основною метою якого є просування політики, вигідної Ізраїлю у межах Сполучених Штатів. Проізраїльське лобі не представляє ні державу Ізраїль, ні єврейський народ у цілому. Натомість воно характеризується приватними особами, підприємствами та організаціями, які хочуть бачити запровадження політики, яка, на їхню думку, $\epsilon$ вигідною для Ізраїлю та відносин між США та Ізраїлем.

У своїй книзі «Ізраїльське лобі та зовнішня політика Сполучених Штатів Америки» американські політологи Джон Міршаймер та Стівен Уолт дають наступне визначенню: «зручний скорочений термін для позначення вільної коаліції осіб та організацій, які активно працюють над формуванням зовнішньої політики США у проізраїльському напрямку» [15]. Вони розвивають це визначення, заявляючи: «щоб бути частиною лобі... потрібно активно працювати над тим, щоб американська зовнішня політика рухалася у проізраїльському напрямку. Для організації це прагнення повинно бути важливою частиною іiї місії та споживати значну частину її ресурсів та порядку денного. А для людини це означає присвятити певну частину своєї професійної або особистого життя (або, у деяких випадках, значну суму грошей) «впливу на політику США на Близькому Сході». Більш того, на відміну від багатьох своїх прихильників, політологи Джон Міршаймер та Стівен Уолт обережно відзначають, що: «лобі-це не єдиний, об'єднаний рух з центральним керівництвом, однак окремі особи та групи, що становлять цю широку коаліцію, іноді розходяться у думках 3 конкретних питань» [15]. Автори повторюють цей момент пізніше, коли пишуть, що «було б неправильно думати про лобі як про цілеспрямований моноліт». На їхню думку, ізраїльське лобі складається не тільки з формальних лобістських організацій (у першу чергу AIPAC), але і з аналітичних центрів (таких як Вашингтонський інститут близькосхідної політики 
та Єврейський інститут у справах національної безпеки), а також численних окремих американських євреїв, християнських євангелістів та неоконсерваторів. Особливо проблематично включення у ізраїльське лобі неоконсервативних політиків, вчених та мислителів. Неоконсерватори, як євреї, так і неєвреї, не просто лобісти Ізраїлю. Хоча вони дійсно можуть бути проізраїльськи налаштовані у своїх симпатіях, їх найбільше турбують Сполучені Штати, так це їх інтереси, цінності та глобальна роль.

Необхідно більш вузько визначати проізраїльське лобі у Сполучених Штатах. Відносити його виключно до ряду формальних організацій, які намагаються вплинути на американську політику щодо Ізраїлю і в напрямку, який, на їхню думку, відповідає інтересам Ізраіля. Ці групи складаються в основному з американських євреїв, але в даний час також велика кількість сіоністів-євангелістів залучено у проізраїльську діяльність, тому слід використовувати термін проізраїльське лобі, а не єврейське лобі [ ].

Проізраїльське лобі визначається політичним порядком денним, а не релігією або етнічною приналежністю. Таким чином, воно складається з груп, які активно лобіюють уряд Сполучених Штатів з питань, що стосуються Ізраїлю. I групи не обов'язково представляють погляди американських євреїв, ізраїльтян або будь-якого іншого ізраїльського уряду, який перебуває при владі, але деякі можуть намагатися зробити це з різним ступенем успіху.

Ці групи рідко погоджуються між собою, не кажучи вже про те, щоб діяти в унісон. Хоч вони і намагаються просувати інтереси Ізраїлю, але сильно розходяться у поглядах на те, якими $\epsilon$ насправді інтереси Ізраїлю. Деякі групи виступають проти окупації Ізраїлем територій, завойованих у ході Шестиденної війни 1967 року. Інші рішуче підтримують контроль Ізраїлю над цими територіями - з причин безпеки, історичних або релігійних причин (або за їх поєднанню). Деякі підтримують створення палестинської держави на Західному березі та у секторі Газа. Інші категорично проти цього. Деякі люто опираються будь-якому американському тиску на Ізраїль. Інші виступають проти беззастережної підтримки Сполученими Штатами політики Ізраїлю та виступають за більш об’єктивну роль Сполучених Штатів в арабо-ізраїльській миротворчості. Але що об'єднує проізраїльські групи, так це не їхня позиція щодо конкретної політики, а їх ставлення до держави Ізраїль. Непохитна відданість виживання Ізраїлю як єврейської держави - це, по суті, те, що відрізняє проізраїльські групи від інших організацій, що беруть участь у лобіюванні уряду США на Близькому Сході.

Визначення факторів впливу для груп інтересів етнічних меншин

Професор політології в Університеті Південної Каліфорнії Тревор Рубенцер зібрав та проаналізував сучасні фактори, які використовуються протягом усіх існуючих досліджень. Існує одинадцять факторів, які Рубенцер визначив у своєму дослідженні, що вказують на вплив групи інтересів 208 
на зовнішню політику: чи асимільована, об’єднана, організована, політично активна чисельна група інтересів етнічних меншин; і має громадську підтримку, зв’язки з рідною країною, значну політичну опозицію, фінансові ресурси, цілеспрямоване послання та союзи з іншими групами інтересів [20]. Тревор Рубенцер знайшов два фактори, які є найбільш вагомими - ступінь політичної участі у зовнішній політиці та організаційна сила лобі.

Спираючись на фактори Т. Рубенцера та два додаткові фактори, ми використовуємо чотири фактори, щоб визначити вплив проізраїльського лобі у США: 1) політична участь у зовнішній політиці; 2) політична опозиція; 3) організаційна сила; 4) політична єдність.

Незважаючи на те, що Тревор Рубенцер включив у свій аналіз літератури одинадцять факторів, є лише чотири, що мали суттєві підтверджуючі докази та могли бути застосовані до проізраїльського лобі. Крім того, багато факторів можна було б включити до інших факторів. Наприклад, фінансові ресурси також можуть бути включені при визначенні організаційної сили лобі етнічних меншин.

При кожному аналізі груп інтересів етнічних меншин потрібно мати два основних фактори: участь у зовнішній політиці та організаційна сила. Однак Тревор Рубенцер пояснює, що ці фактори можна поєднувати 3 іншими факторами: «Мої результати свідчать про те, що політична діяльність та організація $\epsilon$ ключовими факторами, що визначають наявність або відсутність впливу. У цьому сенсі може існувати кілька шляхів впливу...». Його висновки свідчать про те, що основні фактори можна поєднувати з іншими факторами.

Важливо включати як політичну опозицію, так і об'єднання з ключовими факторами Тревора Рубенцера, дивлячись на проізраїльське лобі. Якщо існує значний політичний спротив лобі, воно може боротися за прийняття політики через відкриту опозицію i, таким чином, може бути під посиленим контролем. Це зробило б його набагато менш ефективним, особливо якби ключові члени Конгресу, на яких намагалося вплинути лобі, були відверто проти лобі. Подібно до політичної опозиції, якщо у певному лобі є розкол, це може підірвати цілі лобі. Також може існувати кілька фракцій, які змагаються за різну політику, яка, як вони вважають, є вигідною. Якщо у лобі немає єдності, це може негативно позначитися на повідомленні та вплинути на політику [20]. Крім того, нещодавно відбулися розбіжності у проізраїльському лобі, що робить єдність важливим фактором.

Проізраїльське лобі зосереджується насамперед на зовнішній політиці.

Ступінь участі лобі у зовнішній політиці є безперечно ключовою при визначенні впливу групи інтересів меншості на зовнішню політику. Дивлячись на проізраїльське лобі, переважна більшість питань, якими воно займається, стосується зовнішньої політики; зокрема, зовнішня політика, 
яка стосується Ізраїлю [9]. Це стає очевидним на веб-сайті організації AIPAC, який містить різні питання, які розглядає. Усі перелічені питання прямо чи опосередковано пов'язані із зовнішньою політикою: починаючи від Ірану та закінчуючи рухом BDS («Бойкот, Ізоляція, Санкції» - створений проти Ізраїлю)та позбавлення прав. Крім того, AIPAC часто спонсорує поїздки до Ізраїлю для нових членів Конгресу та інших прихильників [8]. Ці поїздки проводяться для закріплення прихильності до Ізраїлю та сприяння розвитку відносин між США та Ізраїлем. Таким чином, лобі майже виключно займається питаннями зовнішньої політики, оскільки внутрішня політика США майже не впливає на інтереси держави Ізраїль.

Відмінності між лобістськими групами та зростаючий розкол

Наскільки організаційною силою є група інтересів меншості, можна визначити розміром, ресурсами та можливостями лобіювання групи інтересів. Розмір організації групи інтересів зазвичай визначається кількістю членів, службовців та офісів. Ресурси та можливості лобіювання зазвичай демонструються за рахунок фінансування організацій та можливості найму лобістів. Хоча проізраїльське лобі складається з численних груп інтересів та складається з трьох різних лобі: лівого, центристського та правого. Тому на думку проізраїльського активіста Дена Флешлера: «в організованій, самопроголошеній, проізраїльській американській єврейській громаді існує більше одного лобі та $є$ істотні розбіжності з приводу того, що потрібно Ізраїлю від Сполучених Штатів». Але зосередимо більшу частину аналізу на двох найбільших гравцях лівого лобі J-Street та центристського лобі AIPAC.

Як J-Street, так і AIPAC мають широку мережу офісів та значну кількість персоналу. Обидві організації стверджують, що мають понад 100 ооо членів по всій території CША. J-Street та AIPAC не становлять цілого проізраїльського лобі, але все ж таки є його значною частиною. Крім того, вони допомагають продемонструвати різні структури груп інтересів у проізраїльському лобі. Подібно до розміру групи інтересів, ресурси та можливості лобіювання також $\epsilon$ важливими факторами для визначення організаційної сили групи інтересів [20].

Проізраїльське лобі широко відоме на політичній арені як таке, що має значні фінансові ресурси та можливості лобіювання. Зокрема, AIPAC визнаний одним із ключових гравців у політиці США. У 2007 році конгресмен від Демократичної партії Джим Моран визнав, що AIPAC, як відомо, є ключовим гравцем у політиці: «Кожен учасник знає, що це найкраще організована національна лобістська сила» [7]. Білл Клінтон також визнав AIPAC «надзвичайно ефективним» та «кращим за будь-кого при лобіюванні у Вашингтоні» [9]. Навіть сама організація визнала свою силу завдяки цитаті, опублікованій на власному веб-сайті з видавництва «New York Times», де AIPAC називався «найважливішою організацією, що впли- 
ває на відносини Америки з Ізраїлем» [18]. I це лише кілька свідчення про силу та присутність AIPAC у політиці.

AIPAC протягом десятиліть мав налагоджену мережу у Сполучених Штатах, але інша лобістська організація J-Street стала важливим гравцем проізраїльського лобі. Обидві організації добре організовані та мають доступ до багатьох ресурсів. Таким чином, вони є яскравими прикладами організаційного фактора, за Тревором Рубенцеру.

Проізраїльське лобі стикається із постійно зростаючим розривом в залежності від членства прихильників. Ще донедавна AIPAC був обличчям проізраїльського лобі. Проізраїльське лобі історично було більш прихильним до того, що хотів уряд Ізраїлю, і рідко відрізнялося від самопроголошених ізраїльських інтересів. Однак це змінилося із збільшенням усвідомлення конфлікту між палестинцями та Ізраїлем. 3 огляду на це, такі ліві організації, як J-Street та «IfNotNow», виникли у тих сферах політики, які були в основному недостатньо представлені у проізраїльському лобі. Замість звичайної консервативної та пролікудської партійної політики AIPAC, нові групи інтересів просували мир. Консервативний ізраїльський уряд не бажав такого підходу, групи все ще могли наполягати на політиці, яка, на їх думку, була вигідною для Ізраїлю.

Позициї AIPAC ma J Street у ключових питаннях та фінансові витрати на лобіювання

Ізраӥльсько-палестинське вирішення (концепція «дводержавносmi»): AIPAC- підтримує [2]; J Street-підтримує.

Визнання Єрусалиму столицею Ізрайлю: АІРАC-підтримує; J Street - підтримує, але США повинні були почекати до появи «дводержавності» [14]

Особливі стосунки між США та Ізраӥлем: АІРАС-підтримує; J Street-підтримує, але це не повинно підривати відносини на Близькому Сході.

Рух BDS («Бойкот, Ізоляциія, Санкциї» - створений проти Ізраӥлю): AIPAC - протидіє; J Street - виступає проти, крім поглядів BDS, пов’язаних із «дводержавністю» [13].

Іранська ядерна угода: AIPAC - протидіє [21]; J Street-підтримує.

Аналізуючи позиції з питань, що стосуються Ізраїлю, AIPAC та J-Street поділяють багато однакових точок зору. Їх бачення в основному різниться між собою щодо вирішення кожного питання, але часто вони мають одну і ту ж кінцеву мету. Наприклад, питання BDS (рух, створений з метою тиску на Ізраїль економічними засобами). AIPAC, так як і J-Street загалом виступають проти руху, але J-Street підтримує BDS у питанні «дводержавності» [3]. Незважаючи на те, що J-Street часто пропонує інший метод вирішення питань, але що стосуються Ізраїлю, має загальні точки зору з AIPAC. 
Основна проблема, з якою AIPAC та J-Street не погоджуються - це Іранська ядерна угода. Угода відміняла економічні санкції проти Ірану, якби він погодився не продовжувати свою програму ядерної зброї. Правий уряд Ізраїлю виступав проти іранської ядерної угоди, оскільки вважав, що це надасть Ірану більше влади у регіоні без додаткового тягаря економічних санкцій. АIPAC поділяє погляди Ізраїлю, але інші проізраїльські групи інтересів, такі як J-Street, підтримали угоду [3]. Більш ліберальні групи інтересів підтримали угоду, вважаючи, що це фактично зупинить Іран від отримання ядерної зброї. Вони вважали, що якщо програма ядерної зброї продовжиться, може бути збільшена ймовірність конфлікту між Ізраїлем, Іраном та їхніми союзниками.

Іранська ядерна угода наголосила на зростаючому розриві у проізраїльському лобі. Розбіжність базувалася переважно за партійними приналежностями: консервативна проти ліберальної. Загалом ліберальна сторона проізраїльського лобі підтримала угоду, тоді як консервативна сторона виступила проти угоди. До цього моменту обидві сторони політичного спектру мали відносну підтримку щодо зовнішньої політики Ізраїлю [6].

Згідно даних некомерційної дослідницької групи «Центр відповідальної політики», яка досліджує вплив грошей та лобізму на вибори та державну політику Сполучених Штатів, у період з 2010 року по 2020 рік найбільші витрати, виділенні на лобіювання, від проізраїльської групи AIPAC, що складає 33 мільйони 242 тисячі доларів. За останній рік, без урахування четвертого кварталу, витрати сягають 1 мільйону 963 тисячам доларів. Інша лобістська група J-Street витратила 3 мільйони 820 тисяч доларів. А за останній рік-30о тисяч доларів [11].

Роль лобістських груп у прийнятті зовнішнъополітичних рішень адміністрацією Сполучених Штатів

Одним із основних аргументів щодо впливу проізраїльського лобі $\epsilon$ те, що воно ефективне з точки зору лобіювання Конгресу, але мало впливає на рішення, прийняті президентом. Дослідженням цієї теорії займався політичний аналітик та експерт з зовнішньої політики США на Близькому Сході Мітчелл Бард, який проаналізував 782 політичних рішення в період з 1945 по 1984 роки. Проізраїльське лобі досягло своєї політичної мети у 6о\% випадків. Однак він виявив, що у випадках, коли президент підтримував лобі, воно вигравало у 95\% випадків. 3 цього дослідження Мітчелл Бард дійшов висновку, що, хоча лобі і має значну владу у Конгресі, але значно менше впливає на рішення виконавчої влади та на законодавчі рішення, які стосуються безпеки та дипломатії, за що Конгрес часто доручає президенту16. Хоча дослідження Мітчелла Барда є важливими для отримання більш точного розуміння впливу проізраїльського лобі, його пояснювальні можливості обмежуються лише періодом до 1984 року, але аналітик визнав, що після американьско-ізраїльські відносини, та лобіювання стали міцнішими.

212 
Також Мітчелл Бард пояснює, що наразі організовані групи намагаються безпосередньо вплинути на законодавство Сполучених Штатів. Однією із таких груп є зареєстроване лобі, наприклад, АIPAC. Інші групи, як правило, не займаються прямим лобіюванням (наприклад, найстаріша організація «Бней-Брит» та жіноча сіоністська організація «Хадасса»), але поширюють інформацію та заохочують своїх членів брати участь у політичному процесі. Іноді вони лобіюють певні питання, хоча рідко впливають на політику [4].

Політика США на Близькому Сході надалі формується поведінкою євреїв щодо голосування на виборах та американською громадською думкою. Ці непрямі засоби впливу є неформальним лобі.

Формальна та неформальна складові, як правило, перетинаються в декількох точках, тому різниця не завжди є чіткою. Однак разом вони утворюють проізраїльське лобі. Лобі можна визначити як сукупність формальних та неформальних суб'єктів, які прямо та опосередковано впливають на американську політику підтримки Ізраїлю.

Американські євреї визнають важливість підтримки Ізраїлю через жахливі наслідки, які можуть випливати з альтернативних рішень. Незважаючи на те, що Ізраїль сьогодні часто називають четвертою за потугою країною у світі, сприйнята Ізраїлем загроза - це не військова поразка, а знищення. Як результат, євреї присвятили себе політиці майже з релігійним запалом. На це вказує той факт, що єврейське голосування також має значення, оскільки населення зосереджене у ключових штатах. Хоча єврейське населення США становить лише трохи більше 7 мільйонів (близько 2\% від загальної кількості населення країни), 10 штатів 3 найбільшою концентрацією населення мають 2443270 виборчих голосів, необхідних для обрання президента.

Політична активність євреїв змушує конгресменів з президентськими амбіціями розглянути ті питання, які пов’язанні із Ізраїлем, у політичному майбутньому. Кандидати, які займають відверто антиізраїльську позицію, не мають ніякої вигоди та втрачають внески до передвиборної кампанії, так як і голоси єврейського та неєврейського населення. Тому потенційні кандидати мають стимул бути прихильниками Ізраїлю та це посилює підтримку Ізраїлю у Конгресі. Фактичні кандидати повинні бути особливо чутливими до проблем єврейських виборців. Одним із способів, яким лобісти завойовують прихильність політиків - поїздки до Ізраїлю для ознайомлення. Як тільки чиновники мають зв’язок з країною, їі лідерами, географію та питанням щодо безпеки, вони, як правило, стають до Ізраїлю більш прихильнішими. Політики також іноді їздять до Ізраїлю спеціально, щоб продемонструвати лобі свою зацікавленість в Ізраїлі. Так, наприклад, Джордж Буш молодший, обіймаючи посаду губернатора штату Техас, здійснив свою єдину поїздку до Ізраїлю, перш ніж прийняти рішення балотуватися у президенти, 
що широко розглядалося як спроба завоювати підтримку проізраїльських виборців [8]. Ця поїздка була організована Республіканською Єврейською Коаліцією (РЄК), створеною у 1985 році, яка об’єднує у загальноамериканському масштабі євреїв-республіканців, активістів партії, інтелектуалів та спонсорів [19]. За часів адміністрації Джорджа Буша молодшого РЄК стала однією з провідних сил у правлячій партії та могутнім інструментом впливу на Білий Дім, Державний Департамент, Конгрес. У 2002 році президент підписав зовнішньополітичну програму США на 2003 рік, в якій містився пункт про визнання Єрусалиму столицею Ізраїлю та перенесення посольства Сполучених Штатів з Тель-Авіву до Єрусалиму, що спровокувало супротив та критику серед конгресменів того часу. Однак, реалізація цього пункту стала можливою лише під час президенства Дональда Трампа, який 6 грудня 2017 року оголосив промову, в якій Єрусалим визнавався столицею Ізраїлю та посольство переноситься до Єрусалиму від травня 2018 року. Також своїми політичними рішеннями Дональд Трамп став найбільш проізраїльським президентом Сполучених Штатів, оскільки виконав більшу частину лобістських задач: окрім перенесення посольства до Єрусалиму; наполягав на посиленні економічних санкцій проти Ірану та обмеженні Ірану доступу до ядерного озброєння; скорочення фінансування для БАДОР («Близькосхідне агентство ООН для допомоги палестинським біженцям та організації робіт») задля примусу працювати з Ізраїлем та Заходом; засуджував антиізраїльські резолюції ООН.

Задля прийняття рішення про посольство Дональд Трамп посилався на «Закон про перенесення посольства до Єрусалиму» від 1995 року, прийнятий Конгресом США [12]. У цьому Законі зазначалося: «місто Єрусалим визнається столицею Держави Ізраїль. Перенесення посольства Сполучених Штатів до Єрусалиму має відбутися не пізніше, ніж у 1999 році. Сполучені Штати проводять офіційні бізнес-кампаніїі у місті Єрусалим, де-факто, визнаючи за ним статус столиці Ізраїлю. Єрусалим має бути визнано столицею Держави Ізраїль». Але для запобігання загострення ситуації на Близькому Сході президенти Білл Клінтон, Джордж Буш молодший та Барак Обама багаторазово відкладали реалізацію цього закону, про що регулярно, кожні півроку, сповіщали американський Конгрес, підписуючи постанову про пролонгацію.

Може скластися хибне враження, що проізраїльському лобі завжди вдається легко досягти поставлених цілей. У випадку з центристським лобі AIPAC виникло протистояння з адміністрацією президента Барака Обами [10]. Після вступу на посаду у 2008 році президент Барак Обама визначив перспективу отримання Іраном ядерної зброї як одну з п'яти основних проблем зовнішньої політики, і це зрозуміло, беручи до уваги мінливість гонки ядерних озброєнь у найбільш нестабільному регіоні світу. Ізраїль надзвичайно турбує агресивна риторика Ірану до єврейської держави та його 214 
відмова прийняти право Ізраїлю існувати на історичній землі. У результаті подій в Ірані та реакції Сполучених Штатів на них ізраїльські політики стали все голоснішими щодо своїх надій на адміністрацію Барака Обами та дедалі ворожими щодо адміністрації аятоли Хасана Рухані. У своєму Зверненні до Конгресу у 2014 році президент Барак Обама чітко заявив про свій план накласти вето на будь-який новий санкційний законопроект, переданий йому Конгресом, намагаючись "надати дипломатії шанс на успіх», і він дотримав свого слова [16]. Під час виступу на Генеральній Асамблеї ООН 2013 року президент, повторюючи реалістичну та більш вузько зосереджену зовнішньополітичну програму, заявив про відмову США дозволити Ірану отримати ядерну зброю, але прямо зазначив: «ми не прагнемо зміни режиму, ми поважаємо право іранського народу на доступ до мирної ядерної енергії. Натомість ми наполягаємо на тому, щоб іранський уряд виконував свої обов'язки, передбачені Договором про нерозповсюдження ядерної зброї та резолюціями Ради Безпеки ООН». Натомість група AIPAC заявляла щодо Ірану свою однозначну вимогу - припинити ядерну програму та відіграти важливу роль у досягненні цієї мети Сполучені Штати. На сайті організації зазначалося, що «американська політика повинна без зусиль намагатися перешкодити Ірану досягти ядерної зброї. Ядерно-озброєний Іран є екзистенціальною загрозою для Ізраїлю». AIPAC спеціально закликає Конгрес Сполучених Штатів здійснити, як він вважає, необхідні кроки щодо запобігання ядерній зброї Ірану [1]. У політичній пам'ятці щодо проміжної угоди між Іраном та Р 5 + 1 (5 постійних членів Ради Безпеки ООН + Німеччина) AIPAC виклав конкретні кроки, які він очікував від Конгресу, включаючи суворий контроль за дотриманням Іраном правил, умови остаточної угоди про потенційні можливі наслідки, якщо Іран порушить угоду [21]. Проте, у адміністрації Барака Обами було своє бачення, яке призвело до послаблення економічних санкцій проти іранського режиму та посилення ядерної програми. Надалі це спровокувало погіршення відносин між президентом Бараком Обамою та прем'єр-міністром Ізраїлю Бен'яміном Нетаньяху, та виразилося у підтримці Сполученими Штатами антиізраїльських резолюції в ООН.

\section{Висновки}

Отже, можна виділити наступні технології зовнішньої політики Ізраїлю через лобіювання проізраїльских груп у Сполучених Штатах: фінансова підтримка конгресменів та сенаторів, організація поїздок до єврейської держави, ініціювання та проведення обговорення проблем у Конгресі та Сенаті, влаштування щорічних з"їздів за участю американських та ізраїльських високопосадовців.

Проізраїльське лобі представлено не як єдине ціле, але як конгломерат трьох різних та конкуруючих лобі, які часто працюють суперечливо 
між собою, але мають одну ціль - покращення американсько-ізраїльських відносин та вирішення безпекових питань Ізраїля. Проізраїльське лобі у Сполучених Штатах вважається ефективним, оскільки єврейська держава отримує двопартійну підтримку у вигляді щорічної фінансової допомоги. На сьогодні Сполучені Штати надали Ізраїлю 146 мільярдів доларів (поточних доларів або з урахуванням інфляції доларів) як двосторонню допомогу та фінансування протиракетної оборони. В даний час майже вся двостороння допомога Сполученими Штатами Ізраїлю здійснюється у формі військової допомоги, хоча 31971 по 2007 рік Ізраїль також отримував значну економічну допомогу. У 2016 році уряди США та Ізраїлю підписали свій третій десятирічний «Меморандум про взаєморозуміння про військову допомогу». Відповідно до умов «Меморандуму про взаєморозуміння», Сполучені Штати пообіцяли надати Ізраїлю - за умови асигнувань у Конгресі-38 мільярдів доларів військової допомоги (33 мільярди доларів у вигляді грантів на іноземне військове фінансування та щ 5 мільярдів доларів на протиракетну оборону). Цей «Меморандум про взаєморозуміння» був реалізований за попередньою десятирічною угодою на 30 мільярдів доларів, яка діяла протягом 2018 фінансового року.

\section{Список посилань:}

1. AIPAC Memo, 'Congress Must Act to Ensure Iranian Compliance' http://www. aipac. org/media/Publications/PolicyandPolitics/ AIPACAnalyses/IssueMemos/2014/AIPACMemo-CongressMusActo EnsureIranianCompliance. pdf.

2. AIPAC underscores commitment to two-state solution https://www. timesofisrael. com/aipac-underscores-commitment-to-two-state-solution/

3. A Two-state Solution Is Possible\&Necessary https://jstreet. org/ two-state-solution-possible-necessary/

4. Bard, M. 'The Pro-Israel \& Pro-Arab Lobbies' https://www. jewishvirtuallibrary. org/the-pro-israel-and-pro-arab-lobbies

5. Beauchamp, Z. 'Why the US has the most pro-Israel foreign policy in the world'

6. https://www. vox. com/2014/7/24/5929705/us-israel-friends

7. Broder, J. 'How the Iran Nuclear Deal Weakened AIPAC, Washington's Most Powerful Interest Group' https://www. newsweek. com/2015/o9/11/whos-afraid-israel-lobby-367368.html.

8. Burns, A. 'Senator Menendez's Legal Fund Raised $\$ 431,000$ in First Quarter of 2015' https://www. nytimes. com/2015/04/16/nyregion/ senator-robert-menendezs-legal-fund-raised-431000-in-firstquarter-of-2015.html.

9. Bykowicz, J., N. Andrews 'Pro-Israel Group Lobbies for U.S. Aid, Funds Congressional Trips' https://www. wsj. com/articles/pro-israelgroup-lobbies-for-u-s-aid-funds-congressional-trips-11550174834. 
10. Callahan, D. 'The Super-Rich Have Found a New Way to Wield Political Power: Philanthropy' https://www. thenation. com/article/archive/thesuperrich-have-found-a-new-way-to-wield-political-power-philanthropy/

11. Carol E.L., Solomon J. 'Pro-Israel Group Publicly Breaks With White House Over Iran’ https://www. wsj. com/articles/pro-israel-grouppublicly-breaks-with-white-house-over-iran-1425245094.

12. Center for Responsive Politics. 'Pro-Israel: Long-Term Contribution Trends OpenSecrets' https://www. opensecrets. org/industries/ totals. php?cycle $=$ All\&ind $=$ Q05

13. Jerusalem Embassy Act Of 1995 https://www. congress. gov/104/ plaws/publ45/PLAW-104publ45.pdf

14. J-Street policy principles on the Global BDS Movement and boycotts, divestment and sanctions https://jstreet. org/policy/ boycott-divestment-and-sanctions-bds

15. J-Street says it supports the right to boycott and anti-BDS resolution https://www. timesofisrael. com/j-street-says-it-supports-right-toboycott-and-anti-bds-legislation/

16. Mearsheimer, J., Walt S. M. 'The Israel Lobby and U.S. Foreign Policy' https://www. foreignaffairs. com/reviews/capsule-review/2006-09o1/israel-lobby-and-us-foreign-policy.

17. OfficeofthePressSecretary,'PresidentBarackObama'sStateoftheUnion Address', http://www. whitehouse. gov/the-pressoffice/2014/01/28/ president-barack-obamas-state-union-address.

18. Pro-Israel AIPAC lobby navigates US political changes https:// www. dw. com/en/pro-israel-aipac-lobby-navigates-us-politicalchanges/a-48020059

19. Rabinowitz, D. 'First They Came for the Jews' https://www. wsj. com/ articles/SB117547068119856282.

20. Republican Jewish Coalition https://www. jewishvirtuallibrary. org/ republican-jewish-coalition.

21. Rubenzer,T.'EthnicMinorityInterestGroupAttributesandU.S.Foreign Policy Influence: A Qualitative Comparative Analysis' Foreign Policy Analysis, https://doi. org/10.1111/j. 1743-8594.2007.00063.x

22. The Iran Nuclear Deal: What You Need To Know About The JCPOA https://www. jewishvirtuallibrary. org/jsource/US-Israel/jcpoa_ what_you_need_to_know. pdf

23. U.S. Foreign Aid to Israel https://fas. org/sgp/crs/mideast/RL33222.pdf

24. Yaroni, M. 'Transforming America's Israel Lobby' https://jewcy. com/post/transforming_americas_israel_lobby

Стаття надійшла до редакції 27.03.2020 р.

(C) Негіна В. Р., Висоцький О. Ю., 2020 